\title{
An Assessment Model for Hydrogen Fuel Cell Applications: Fuzzy Delphi Approach
}

\author{
Pao-Long Chang and Chiung-Wen Hsu
}

\begin{abstract}
The objective of this study is to develop an assessment model that can be used to evaluate hydrogen fuel cell applications and provide a screening tool for decision makers. This model operates by selecting the evaluation indicators, determining criteria weight, and assessing the performance of hydrogen fuel cell applications with respect to each criterion. The fuzzy Delphi method (FDM) was used to select the criteria and the preferred hydrogen fuel cell products based on the information collected from a group of experts. Survey questionnaires were sent out to obtain the opinions of experts in different fields. After two rounds of surveying, the group consensus, criteria weight, and ranking of options were obtained. The selected criteria included four general fields-environment, technology, economy, and society, 14 indicators such as energy efficiency and $\mathrm{CO}_{2}$ emission, and seven hydrogen fuel cell applications such as fuel cell forklifts and fuel cell backup power systems. The results show that the fuel cell backup power system ranked the highest, followed by household fuel cell electric-heat composite systems. The criteria provide a screening tool for decision makers to select appropriate hydrogen-related applications.
\end{abstract}

Index Terms-Fuel cell, hydrogen, fuzzy delphi, evaluation indicator, assessment model

\section{INTRODUCTION}

A hydrogen economy is based on the application of hydrogen to replace fossil energy. The development of hydrogen energy technology is far from large-scale applications. However, because hydrogen energy technology is still emerging, there are uncertainties and obstacles to promoting hydrogen energy applications. For example, which technologies and products should be high priorities? How can costs be reduced and safety ensured? What infrustrure should be updated and developed? How should new products be regulated, and what standards should be modified and implemented? Often, government involvement is necessary to address these questions and challenges.

However, transforming the current fossil-fuel based economic system into one based on hydrogen will require long-term technological development and changes to the related industries and social systems. The development of hydrogen energy technology relies on mature, reliable, and economically competitive fuel cell products to promote the growth of the hydrogen economy [1-3]. To speed up the

Manuscript received September 2, 2011; revised September 29, 2011.

Pao-Long Chang is with Department of Business Administration, Feng Chia University, Taichung, Taiwan.

Chiung-Wen Hsu is with Graduate Institute of Management of Technology, Feng Chia University, Taichung, Taiwan process of new energy technology development and product applications, many nations have adopted policies, such as research incentives and demonstrative product application programs, to help companies reduce development costs and to establish a preliminary product application market.

The scope of fuel cell applications is quite broad and includes various types of products such as transportation motorcycles and fixed and portable power systems. Due to limited resources, the selection of suitable fuel cell products for development and demonstrative promotion is necessary to implement technological and industrial government policies. Faced with an array of diverse fuel cell applications, Taiwan's government, on the one hand, hopes to promote development of related industries to achieve the policy objective of energy conservation, and, on the other hand, it must consider the best way to apply limited development and subsidy funds toward the most suitable products. Therefore, identifying an effective hydrogen application assessment model to aid the government in selecting products for development has become an important research topic.

The purpose of this study is to assist the decision-making units of the government, within the policies of energy conservation and in the development of the hydrogen energy industry, in establishing a fuel cell product assessment model to select high-priority products for development in Taiwan. Within this model, the assessment criteria are based on the hydrogen energy policy development objectives to ensure that the selected fuel cell applications are the most suitable for the government's long-term objectives.

Many studies on hydrogen-related technologies have adopted a multi-criteria decision-making (MCDM) method to evaluate the versatility of energy system options. Afgan et al. [4] used a multi-criteria assessment method to assess five types of hydrogen application systems. Tzeng et al. [5] adopted the MCDM to evaluate eight new energy systems. Wang et al. [6] also adopted a fuzzy MCDM model to assess trigeneration systems. However, few studies have used the fuzzy Delphi method (FDM) as one method of the MCDM family specifically to evaluate hydrogen fuel cell applications.

In addition to using the MCDM method, it is also recommended that information be collected by means of group decision making and discussions among experts; the Delphi method satisfies this recommendation [7]. Although the Delphi method has been widely applied in many management fields, such as forecasting public policy, the selection of alternative solutions, and project planning $[8,9]$, the traditional Delphi method has been criticized for its low convergence in generating results, the long process of interrogation, and the loss of valuable information from 
expert opinions.

Due to the drawbacks of the traditional Delphi method, many scholars have attempted to improve it in a fuzzy environment. For example, Ishikawa et al. [10] combined the fuzzy set theory in the Delphi method and developed max-min and fuzzy integration algorithms to predict the diffusion of personal computers. Kaufmann et al. [11] also introduced fuzzy logic to evaluate the process of design projects. Murray et al. [12] proposed improving the Delphi method in a fuzzy environment. Further, researchers have adopted this method to solve the fuzziness of a group consensus by combining the FDM and a linguistic variable [8;13-15]. Kaufmann and Gupta [16] and Kuo and Chen [13] described the merits of using FDMs, such as avoiding the distortion of expert opinions, clearly expressing the semantic structure of selected options, and the consideration of the fuzzy nature of the survey process.

Hence, by considering the MCDM and the Delphi methods, this study uses the FDM as an evaluation base to assess various fuel cell applications. This paper is organized as follows. Section 2 introduces the process of the FDM to assess the expert consensus and list the alternative options in the order of their preference. Section 3 identifies the options among fuel cell applications and the evaluation criteria. Section 4 discusses fuel cell applications to illustrate the process of using the FDM to enable field experts to determine the optimal applications for various fuel cells. A discussion of the results and the conclusions are presented in Section 5. The results are expected to indicate valuable implications for policy makers and fuel cell related industries.

\section{FUZZY DELPHI METHOD}

Expert questionnaires are a useful tool for data collection in a Delphi survey when interviewing individuals is not possible in terms of time and group arrangement [7]. The questions were derived from related literature and suggested by experts in an open format.

TABLE I: LINGUISTIC VARIABLES FOR THE IMPORTANCE WEIGHT OF CRITERIA

\begin{tabular}{ll}
\hline Linguistic variable (EU) & Fuzzy scale \\
\hline Extremely unimportant (NV) & $(0.0,0.0,0.1)$ \\
\hline Not very important (NI) & $(0.0,0.1,0.3)$ \\
\hline Not important (F) & $(0.1,0.3,0.5)$ \\
\hline Fair (F) & $(0.3,0.5,0.7)$ \\
\hline Important (I) & $(0.5,0.7,0.9)$ \\
\hline Very important (VI) & $(0.7,0.9,1.0)$ \\
\hline Extremely important (EI) & $(0.9,1.0,1.0)$ \\
\hline
\end{tabular}

TABLE II: LINGUISTIC VARIABLES FOR THE RATING OF ALTERNATIVES

\begin{tabular}{ll}
\hline Linguistic variable & Fuzzy scale \\
\hline Very low (VL) & $(0.0,0.0,0.1)$ \\
\hline Medium low (ML) & $(0.0,0.1,0.3)$ \\
\hline Low (L) & $(0.1,0.3,0.5)$ \\
\hline Fair (F) & $(0.3,0.5,0.7)$ \\
\hline High (H) & $(0.5,0.7,0.9)$ \\
\hline Medium high (MH) & $(0.7,0.9,1.0)$ \\
\hline Very high (VH) & $(0.9,1.0,1.0)$ \\
\hline
\end{tabular}

Assume that $\mathrm{K}$ experts are invited to determine the importance of the evaluation criteria and the ratings of alternatives with respect to various criteria using linguistic variables. The linguistic variables are then converted into triangular fuzzy numbers as suggested in Tables 1 and 2 .

Let fuzzy numbers $\widetilde{r}_{i j}^{k}$ be the rating of alternative $i$ with respect to criteria $j$ and $\widetilde{w}_{j}^{k}$ be the $\mathrm{j}^{\text {th }}$ criteria weight of the $\mathrm{k}^{\text {th }}$ expert for $i=1, \ldots, m, j=1, \ldots, n$, and $k=1, \ldots, K$, and $\quad \widetilde{r}_{i j}=\frac{1}{\mathrm{~K}} \otimes\left[\widetilde{r}_{i j}^{1} \oplus \widetilde{r}_{i j}^{2} \oplus \cdots \oplus \widetilde{r}_{i j}^{\mathrm{K}}\right]$;

$$
\widetilde{w}_{j}=\frac{1}{\mathrm{~K}} \otimes\left[\widetilde{w}_{j}^{1} \oplus \widetilde{w}_{j}^{2} \oplus \cdots \oplus \widetilde{w}_{j}^{\mathrm{K}}\right],
$$

where the operation laws for two triangular fuzzy numbers $\tilde{m}=\left(m_{1}, m_{2}, m_{3}\right)$ and $\tilde{n}=\left(n_{1}, n_{2}, n_{3}\right)$ are as follows: $\tilde{m} \oplus \tilde{n}=\left(m_{1}+n_{1}, m_{2}+n_{2}, m_{3}+n_{3}\right)$, $\tilde{m} \otimes \tilde{n}=\left(m_{1} n_{1}, m_{2} n_{2}, m_{3} n_{3}\right)$, $a \otimes \tilde{m}=\left(a m_{1}, a m_{2}, a m_{3}\right), a>0$.

For each expert, we use the vertex method to compute the distance between the average $\widetilde{r}_{i j}$ and $\widetilde{r}_{i j}^{k}$ and the distance between the average $\widetilde{w}_{j}$ and $\widetilde{w}_{j}^{k} ; k=1, \cdots, K$ (see Chen [17]). This distance is used to measure the deviation between the average fuzzy evaluation and the experts' evaluation. The distance between two fuzzy numbers $\widetilde{m}=\left(m_{1}, m_{2}, m_{3}\right)$ and $\tilde{n}=\left(n_{1}, n_{2}, n_{3}\right)$ is computed by using

$d(\tilde{m}, \tilde{n})=\sqrt{\frac{1}{3}\left[\left(m_{1}-n_{1}\right)^{2}+\left(m_{2}-n_{2}\right)^{2}+\left(m_{3}-n_{3}\right)^{2}\right]}$

According to Cheng and Lin [18], if the distance between the average and the expert's evaluation data is less than the threshold value of 0.2 , then all the experts are considered to have achieved a consensus. Furthermore, among the $m \times n$ ratings of alternatives and $n$ criteria weights, if the percentage of achieving a consensus is greater than $75 \%$ [19,20], then we calculate the fuzzy evaluation of each alternative. Otherwise, a second survey round is required.

The fuzzy evaluation of alternative $i$ is given by

$$
\begin{aligned}
& \widetilde{A}_{i}=\widetilde{r}_{i 1} \otimes \widetilde{w}_{1} \oplus \widetilde{r}_{i 2} \otimes \widetilde{w}_{2} \oplus \cdots \oplus \widetilde{r}_{i n} \otimes \widetilde{w}_{n} \\
& i=1, \cdots, m .
\end{aligned}
$$

For ranking the alternatives, the fuzzy evaluation

$$
\begin{aligned}
& \widetilde{A}_{i}=\left(a_{i 1}, a_{i 2}, a_{i 3}\right) \text { is defuzzified [21] by using } \\
& a_{i}=\frac{1}{4}\left(a_{i 1}+2 a_{i 2}+a_{i 3}\right) .
\end{aligned}
$$

The ranking order of alternatives can be determined according to the values of $a_{i}$.

\section{THE OPTIONS AND EVALUATION CRITERIA FOR FUEL CELl APPLiCATIONS}

\section{A. Selection of options for fuel cell application}

The purpose of establishing a fuel cell application 
assessment model in this study is to assist government decision-making units in selecting suitable products for development and demonstrative promotion. Therefore, the fuel cell products of the future application market are currently not included in the assessment options, and selections are mostly from products in the early or developing application markets. In this study, assessment options from the early application market included fuel cell forklifts, backup power systems, household electric-heat composite systems, portable power installations, and distributed power generation systems. Options from the developing application market were limited to fuel cell motorcycles and power modules for computer, communication, and consumer (3C) products. Taiwan currently has over 10 million gasoline-powered motorcycles, a complete motorcycle industry chain, and has made world-class achievements in the development of fuel cell motorcycles. In addition to, Taiwan is the world's foremost base for developing and producing $3 \mathrm{C}$ products, and several companies have begun developing them. On the other hand, although fuel cell vehicles, a primary hydrogen energy application, have already been prepared for commercialization, their development has been limited in Taiwan due to their complex technologies and high development investment and industry threshold requirements. Therefore, fuel cell vehicles were not included in this study's selected options.

This study used the following seven types of fuel cell products as options: (1) Fuel cell motorcycles; (2) Fuel cell forklifts; (3) Fell cell backup power systems; (4) Household fuel cell electric-heat composite systems; (5) Portable fuel cell power facilities; (6) Distributed fuel cell power generation systems; and (7) 3C product fuel cell power modules.

\section{B. Selection of criteria for evaluating fuel cell applications}

Owing to the complexity of evaluating various fuel cell applications, it is not feasible to compare those applications that rely on a single aspect or only a few criteria [22]. Hence, researchers have attempted to develop a holistic view to categorize those criteria in terms of various aspects. Afgan et al. [22] categorized their criteria based on the four aspects of resources, environment, society, and efficiency in assessing selected energy systems. Petrecca and Decarli [23] examined the impact of using hydrogen systems based on technical and economic aspects. Wang et al. [6] and Lund et al. [24] derived their criteria based on the aspects of technology, economy, environment, and society. Hence, this study selected criteria derived from the four aspects of environment, technology, economy, and society.

\section{Evaluation criteria from an environmental perspective}

1) Energy efficiency: Afgan and Carvalho [25] evaluated the sustainability of new and renewable energy power plants; energy efficiency was one of the assessment criteria. In this study, energy efficiency is defined as the ratio between the energy efficiency of the fuel cell product and the traditional energy product.

2) $\mathrm{CO}_{2}$ emission: This criterion has been used by many scholars studying hydrogen energy and new energy technologies/products [26,27]. In this study, carbon emission is defined as the ratio between the $\mathrm{CO}_{2}$ emitted by fuel cell products and the $\mathrm{CO}_{2}$ emitted by traditional energy products.

\section{Evaluation criteria from a technological perspective}

1) Reliability: Jacobs [28] used system reliability as an assessment criterion. Fuel cell products are newly developed products and there is much room for improvement in their system reliability. In this study, reliability is defined as the ratio between the fuel cell product's reliability and the traditional energy product's reliability.

2) System performance: Afgan and Carvalho [29] used this indicator as an assessment criterion for hydrogen energy systems. In this study, system performance is defined as the ratio between the overall performance of the fuel cell product and that of the traditional energy product.

3) Product maturity: Konstantopoulou et al. [30] used this indicator as an assessment criterion for energy technology. In this study, product maturity is defined as the relative level of technological and systematic maturity of a certain type of fuel cell product compared to that of other products.

4) Product development potential: Konstantopoulou et al. [30] used this indicator as an assessment criterion for energy technology. In this study, product development potential is defined as the relative level of product development potential of a certain type of fuel cell product compared to that of other products.

5) Domestic technological ability: In this study, domestic technological ability is defined as the relative level of domestic technological ability of a certain type of fuel cell product compared to that of other products.

\section{Evaluation criteria from an economic perspective}

1) Acquisition cost: Pilavachi et al. [26,31] used the acquisition cost of energy systems as an assessment criterion. In this study, acquisition cost is defined as the ratio between the acquisition cost of fuel cell products and that of traditional energy products.

2) Use cost: Afgan et al. [4] used this indicator as an assessment criterion for hydrogen systems. In this study, use cost is defined as the ratio between the use cost of fuel cell products and that of traditional energy products.

3) Domestic market demand: Afgan and Carvalho [29] used the European market demand for hydrogen energy systems over the next 10 years as an economic evaluation index. In this study, domestic market demand is defined as the domestic market demand for a certain type of fuel cell product over the next 10 years.

4) Global market demand: Afgan and Carvalho [29] used the global market demand for hydrogen systems over the next 10 years as an economic evaluation index. In this study, global market demand is defined as the global market demand for a certain type of fuel cell product over the next 10 years.

\section{Evaluation criteria from a social perspective}

1) Safeguard: Wang et al. [6] used the safeguarding of surroundings for residents as an assessment criterion for 
new energy systems. In this study, safeguard is defined as the relative level of safety while using a certain type of fuel cell product compared to that of other products.

2) Use environment maturity: Wang et al. [6] used this indicator as an assessment criterion for new energy systems. In this study, use environment maturity is defined as the relative level of environment maturity of a certain type of fuel cell product compared to that of other products.

3) Social acceptability: Konstantopoulou et al. [30] used the level of public willingness to use a new energy system as an assessment criterion. In this study, social acceptability is defined as the relative level of social acceptability of a certain type of fuel cell product compared to that of other products.

\section{Evaluation of Fuel Cell Applications}

Due to the difficulty of selecting the best option among various fuel cell applications, this study used 14 criteria in four aspects to assess seven hydrogen fuel cell applications. A panel of 20 experts from various fields, such as academia and the fuel cell industry, was formed. The evaluation procedures are described as follows.

The experts' information was collected by survey questionnaires. In all, 20 questionnaires were successfully returned and validated. The criteria weight for the 14 criteria and ratings of seven fuel cell applications were converted into fuzzy sets based on the experts' responses on a 7-point Likert scale (Table 3). The scales for three criteria $\left(\mathrm{CO}_{2}\right.$ emission, acquisition cost, and use cost) were reversed based on actual responses, because the value of these three criteria should be as small as possible.

TABLE III: RATINGS OF SEVEN FUEL CELL APPLICATIONS (ONE EXPERT'S RATINGS ARE LISTED AS AN EXAMPLE)

\begin{tabular}{|c|c|c|c|c|c|c|c|c|c|c|c|c|c|c|}
\hline & $\mathrm{c}_{1}$ & $\mathrm{c}_{2}$ & $c_{3}$ & $\mathrm{c}_{4}$ & $\mathrm{c}_{5}$ & $\mathrm{c}_{6}$ & $\mathrm{c}_{7}$ & $\mathrm{c}_{8}$ & $\mathrm{c}_{9}$ & $\mathrm{c}_{1}$ & ${ }_{0} \mathrm{c}_{11}$ & ${ }_{1} c_{12}$ & ${ }_{2} c_{13}$ & $\mathrm{c}_{14}$ \\
\hline $\mathrm{t}_{1}$ & $\mathrm{H}$ & $\begin{array}{l}\mathrm{V} \\
\mathrm{H}\end{array}$ & $\mathrm{F}$ & $\mathrm{F}$ & $\mathrm{F}$ & $\mathrm{F}$ & $\mathrm{F}$ & $\mathrm{MI}$ & L MI & & $\mathrm{F}$ & $\mathrm{F}$ & & $\mathrm{L} \mathrm{F}$ \\
\hline$t_{2}$ & $\mathrm{H}$ & $\begin{array}{l}\mathrm{V} \\
\mathrm{H}\end{array}$ & $\mathrm{F}$ & $\mathrm{H}$ & $\mathrm{F}$ & $\mathrm{MH}$ & H L & MI & L MI & & $\mathrm{H}$ & $\mathrm{F}$ & $\mathrm{L}$ & $\mathrm{F}$ \\
\hline$t_{3}$ & $\mathrm{H}$ & $\begin{array}{l}\mathrm{V} \\
\mathrm{H}\end{array}$ & $\mathrm{H}$ & $\mathrm{Ml}$ & I H & $\mathrm{MH}$ & $\mathrm{HF}$ & $\mathrm{L}$ & $\mathrm{F}$ & $\mathrm{H}$ & $\mathrm{H}$ & $\mathrm{H}$ & $\mathrm{F}$ & $\mathrm{H}$ \\
\hline$t_{4}$ & $\begin{array}{l}\mathrm{V} \\
\mathrm{H}\end{array}$ & $\begin{array}{l}\mathrm{V} \\
\mathrm{H}\end{array}$ & $\mathrm{F}$ & $\mathrm{H}$ & $\mathrm{F}$ & $\mathrm{MH}$ & $\mathrm{H} \mathrm{L}$ & $\mathrm{MI}$ & L L & $\mathrm{F}$ & $\mathrm{H}$ & $\mathrm{F}$ & $\mathrm{L}$ & $\mathrm{F}$ \\
\hline $\mathrm{t}_{5}$ & $\mathrm{H}$ & $\begin{array}{l}\text { V } \\
\mathrm{H}\end{array}$ & $\mathrm{F}$ & $\mathrm{H}$ & $\mathrm{F}$ & $\mathrm{H}$ & $\mathrm{F}$ & $\mathrm{MI}$ & & $\mathrm{F}$ & $\mathrm{F}$ & $\mathrm{F}$ & L & $\mathrm{F}$ \\
\hline $\mathrm{t}_{6}$ & $\mathrm{H}$ & $\begin{array}{l}\mathrm{V} \\
\mathrm{H}\end{array}$ & $\mathrm{F}$ & $\mathrm{H}$ & $\mathrm{F}$ & $\mathrm{MH}$ & $\mathrm{H} \mathrm{L}$ & $\mathrm{MI}$ & L L & $\mathrm{F}$ & $\mathrm{H}$ & $\mathrm{F}$ & $\mathrm{L}$ & $\mathrm{F}$ \\
\hline$t_{7}$ & $\mathrm{H}$ & $\mathrm{H}$ & $\mathrm{F}$ & $\mathrm{F}$ & $\mathrm{F}$ & $\mathrm{F}$ & $\mathrm{L}$ & MI & & $\mathrm{F}$ & $\mathrm{F}$ & $\mathrm{F}$ & L & $\mathrm{F}$ \\
\hline
\end{tabular}

The group consensus was estimated. For example, for expert 1 under the criterion of energy efficiency $\left(\mathrm{c}_{1}\right)$, the average fuzzy weight was $(0.68,0.87,0.98)$ and the original evaluation data were $(0.70,0.90,1.00)$. Hence, the distance between these two fuzzy numbers is 0.03 . The value of 0.03 was less than the threshold value of 0.2 set by this research; thus, it was acceptable for the group consensus. The same rule was applied to the rating of fuel cell applications. For evaluation of the fuel cell motorcycles option under the criterion of energy efficiency, the average fuzzy rating was
$(0.44,0.62,0.80)$ and the original evaluation data were $(0.50$, $0.70,0.90)$. Hence, the deviation was 0.08 , indicating that the group consensus was achieved for this option. To estimate the group consensus, the deviation between the average of group opinions and the experts' evaluation should be equal to or less than 0.2 .

In this study, the criterion that is used to evaluate group consensus was based on the condition that the group agreement is greater than $75 \%[19,20]$. In the first round, the average of criteria weight was $75.71 \%$, and the rating average was $61.68 \%$. Owing to the unsatisfactory result obtained from the first round, the results were sent back to the experts for re-evaluation or revision in the second round. The estimation of the group consensus for the average criteria weight in the second round was $84.29 \%$, and the rating average was $75.05 \%$, which was acceptable. Hence, no further questioning was required after the second round of surveying.

After confirming the group consensus, an average fuzzy weight was formed by each respective criterion (Table 4).

TABLE IV: AVERAGE FUZZY WEIGHTS OF 14 CRITERIA

\begin{tabular}{llc}
\hline $\begin{array}{c}\text { Labe } \\
1\end{array}$ & \multicolumn{1}{c}{ Indicator } & $\begin{array}{c}\text { Fuzzy weight } \\
\left(\widetilde{w}_{j}\right)\end{array}$ \\
\hline $\mathrm{c}_{1}$ & Energy efficiency & $(0.68,0.87,0.98)$ \\
\hline $\mathrm{c}_{2}$ & $\mathrm{CO}_{2}$ emission & $(0.56,0.74,0.89)$ \\
\hline $\mathrm{c}_{3}$ & Reliability & $(0.55,0.74,0.89)$ \\
\hline $\mathrm{c}_{4}$ & System performance & $(0.54,0.73,0.89)$ \\
\hline $\mathrm{c}_{5}$ & Product maturity & $(0.53,0.72,0.87)$ \\
\hline $\mathrm{c}_{6}$ & Product development & $(0.63,0.83,0.96)$ \\
\hline $\mathrm{c}_{7}$ & potential & $\begin{array}{l}\text { Domestic technological } \\
\text { ability }\end{array}$ \\
\hline $\mathrm{c}_{8}$ & Acquisition cost & $(0.57,0.77,0.92)$ \\
\hline $\mathrm{c}_{9}$ & Use cost & $(0.64,0.81,0.92)$ \\
\hline $\mathrm{c}_{10}$ & Domestic market demand & $(0.57,0.77,0.92)$ \\
\hline $\mathrm{c}_{11}$ & Global market demand & $(0.63,0.82,0.95)$ \\
\hline $\mathrm{c}_{12}$ & Safeguard & $(0.60,0.79,0.93)$ \\
\hline $\mathrm{c}_{13}$ & Use environment maturity & $(0.65,0.83,0.94)$ \\
\hline $\mathrm{c}_{14}$ & Social acceptability & $(0.56,0.76,0.91)$ \\
\hline
\end{tabular}

TABLE V: ASSESSMENT OF FUEL CELL APPLICATIONS

\begin{tabular}{|c|c|c|c|}
\hline Option & $\begin{array}{l}\text { Fuzzy evaluation } \\
\left(\widetilde{A}_{i}\right)\end{array}$ & $\begin{array}{l}\text { Score } \\
\left(a_{i}\right)\end{array}$ & $\begin{array}{l}\text { Rank } \\
\text { ing }\end{array}$ \\
\hline Fuel cell motorcycles & $(2.76,5.51,8.75)$ & 5.63 & 7 \\
\hline Fuel cell forklifts & $(3.27,6.38,9.81)$ & 6.46 & 5 \\
\hline $\begin{array}{l}\text { Fuel cell backup } \\
\text { power systems }\end{array}$ & $\begin{array}{l}(3.49,6.70 \\
10.13)\end{array}$ & 6.76 & 1 \\
\hline $\begin{array}{l}\text { Household fuel cell } \\
\text { electric-heat } \\
\text { composite systems }\end{array}$ & $\begin{array}{l}(3.55,6.71, \\
10.01)\end{array}$ & 6.74 & 2 \\
\hline $\begin{array}{l}\text { Portable fuel cell } \\
\text { power facilities }\end{array}$ & $(3.28,6.43,9.95)$ & 6.53 & 4 \\
\hline $\begin{array}{l}\text { Distributed fuel cell } \\
\text { power generation } \\
\text { systems }\end{array}$ & $(3.42,6.54,9.88)$ & 6.60 & 3 \\
\hline $\begin{array}{l}3 \mathrm{C} \text { product fuel cell } \\
\text { power modules }\end{array}$ & $(2.84,5.74,9.11)$ & 5.86 & 6 \\
\hline
\end{tabular}


Seven fuel cell applications $\left(t_{1}, t_{2}, t_{3}, \ldots, t_{7}\right)$ were rated by the same experts by considering the 14 criteria $\left(c_{1}, c_{2}, \ldots, c_{14}\right)$. The average fuzzy ratings are obtained. The experts' preferences for fuel cell applications were assessed by combining the fuzzy ratings and the fuzzy weights. The assessment of various fuel cell applications was conducted by defuzzifying the fuzzy evaluation. Fuel cell applications are thus listed by the order of priority via their score rankings (Table 5).

The fuel cell backup power system was the best option for future development, followed by the household fuel cell electric-heat composite systems and the distributed fuel cell generation systems.

\section{DISCUSSION AND CONCLUSION}

This study used the four fields of environment, technology, economy, and society and 14 assessment indicators for the fuel cell product selection criteria. Results from the FDM showed that of the 14 indicators, the most highly weighted were $c_{1}$ (energy efficiency), $c_{6}$ (product development potential), $\mathrm{c}_{13}$ (use environment maturity), and $\mathrm{c}_{11}$ (global market demand). These four indicators were part of the categories of environment $\left(\mathrm{c}_{1}\right)$, technology $\left(\mathrm{c}_{6}\right)$, social $\left(\mathrm{c}_{13}\right)$, and economy $\left(\mathrm{c}_{11}\right)$. The lower weighted indicators included $\mathrm{c}_{5}$ (product maturity) and $\mathrm{c}_{4}$ (system performance).

Study results showed that of the seven hydrogen fuel cell application products, backup power systems were the best choice, followed by household fuel cell electric-heat composite systems. Their assessment scores were very close; 6.76 and 6.74, respectively. On the other hand, among the seven types of products, fuel cell motorcycles the lowest overall assessment score, because it scored very low on $\mathrm{c}_{8}$ (acquisition cost), $\mathrm{c}_{9}$ (use cost), $\mathrm{c}_{13}$ (use environment maturity), and did not score high on the other indicators either. This also shows that if Taiwan's government and companies wish to continue promoting these motorcycles, the most important action is to reduce cost (including acquisition cost and use cost), as well as speed up the construction of hydrogen refueling stations or hydrogen fuel tank exchange locations.

There are already several companies in Taiwan developing fuel cell backup power system. In addition to, Taiwan also has other developmental advantages, such as abundant mechanical-electrical integrated industries and related support industries, and can reduce fuel cell application system costs from the areas of balance of plant, control, and system integration. Taiwan currently has 40,000 communication base stations, each installed with a $5-\mathrm{kW}$ fuel cell backup power system at a cost of \$10,000-15,000 USD. This will therefore create a potential market of $\$ 400-600$ million USD, an important market asset for Taiwan's development of fuel cell backup power systems.

Based on the development status of fuel cell applications in Taiwan, it is observed that a fuel cell backup power system is more developed than other productions are. In addition, the development activities of fuel cell backup power systems are also encouraged by Taiwan's government. The Bureau of Energy in Taiwan has been conducting a demonstration project on fuel cell applications including backup power systems from 2009. In 2009 and 2010, several companies participated in this project and successfully installed some fuel cell backup power systems in the Taiwan's communication companies. This also shows the consistence between the results obtained from this assessment model and the developing status of fuel cell applications in Taiwan. Moreover, a follow-on study with large samples is suggested to be conducted to validate the findings.

\section{ACKNOWLEDGEMENT}

The authors appreciate the financial support from the National Science Council of Taiwan (NSC 100-3113-P-035-002).

\section{REFERENCES}

[1] H. J. Neef, "International overview of hydrogen and fuel cell research," Energy, vol. 34, pp. 327-333, 2009.

[2] C. J. Winter, "Into the hydrogen energy economy-milestones," International Journal of Hydrogen Energy, vol. 30, pp. 681-685, 2005.

[3] S. S. Penner, "Steps toward the hydrogen economy," Energy, vol.31, pp. 33-43, 2006.

[4] N. H. Afgan, A. Veziroglu, and M. G. Carvalho, "Multi-criteria evaluation of hydrogen system options," International Journal of Hydrogen Energy, vol. 32, pp. 3183-3193, 2007.

[5] G. H. Tzeng, T. A. Shiau, and C. Y. Lin, "Application of multicriteria decision making to the evaluation of new energy system development in Taiwan," Energy, vol. 7, pp. 983-992, 1992.

[6] J. J. Wang, Y. Y. Jing, C. F. Zhang, G H. Shi, and X. T. Zhang, "A fuzzy multi-criteria decision-making model for trigeneration system," Energy Policy, vol. 36, pp. 3823-3832, 2008.

[7] N. Dalkey and O. Helmer, "An experimental application of the Delphi method to the use of experts," Management Science, vol. 9, pp. 458-467, 1963.

[8] P. C. Chang and Y. W. Wang, "Fuzzy Delphi and back-propogation model for sales forecasting in PCB industry," Expert Systems with Applications, vol. 30, pp. 715-726, 2006.

[9] N. C. Dalkey and D. L. Rourke, "Experimental assessment of Delphi procedures with group value judgements," Advanced Research Proejcts Agency, Rand Corporation, Santa Monica, CA, 1971.

[10] A. Ishikawa, M. Amagasa, T. Shiga, G. Tomizawa, R. Tatsuta, and H. Mieno, "The max-min Delphi method and fuzzy Delphi method via fuzzy integration," Fuzzy Sets and Systems, vol. 55, pp. 241-253, 1993.

[11] A. Kaufmann, M. M. Gupta, and B. Esposito, "Introduction to Fuzzy Arithmetic,” New York: Van Nostrand Reinhold Company, 1991.

[12] T. J. Murray, L. L. Pipino, and J. P. van Gigch, "A pilot study of fuzzy set modification of Delphi," Human Systems Management, vol. 5, pp. 76-80, 1985.

[13] Y. F. Kuo and P. C. Chen, "Constructing performance appraisal indicators for mobility of the service industries using Fuzzy Delphi Method," Expert Systems with Applications, vol. 35, pp. 1930-1939, 2008.

[14] Y. L. Hsu, C. H. Lee, and V. B. Kreng, "The application of Fuzzy Delphi Method and Fuzzy AHP in lubricant regenerative technology selection," Expert Systems with Applications, vol. 37, pp. 419-425, 2010.

[15] G. Büyüközkan and D. Ruan, "Evaluation of software development projects using a fuzzy multi-criteria decision approach," Mathematics and Computers in Simulation, vol. 77, pp. 464-475, 2008.

[16] A. Kaufmann and M. M. Gupta, "Fuzzy mathematical models in engineering and management science," New York, NY: Elsevier Science Inc., 1988.

[17] C. T. Chen, "Extensions of the TOPSIS for group decision-making under fuzzy environment," Fuzzy Sets and Systems, vol. 114, pp. 1-9, 2000.

[18] C. H. Cheng and Y. Lin, "Evaluating the best main battle tank using fuzzy decision theory with linguistic criteria evaluation," European Journal of Operational Research, vol. 142, pp. 174-186, 2002.

[19] H. C. Chu and G. J. Hwang, "A Delphi-based approach to developing expert systems with the cooperation of multiple experts," Expert Systems with Applications, vol. 34, pp. 2826-2840, 2008. 
[20] J. W. Murry and J. O. Hammons, "Delphi: A versatile methodology for conducting qualitative research," Review of Higher Education, vol. 18, pp. 423-436, 1995

[21] S. M. Chen, "Evaluating weapon systems using fuzzy arithmetic operations." Fuzzy Sets and Systems. 1996, 77: 265-76.

[22] N. H. Afgan, M. G. Carvalho, and N. V. Hovanov, "Energy system assessment with sustainability indicators," Energy Policy, vol. 28, pp. 603-612, 2000.

[23] G. Petrecca and M. Decarli, "A review of hydrogen applications: technical and economic aspects," Paper presented at the Electrotechnical Conference, MELECON 2008. The $14^{\text {th }}$ IEEE Mediterranean Ajaccio, pp. 658-662, 2008.

[24] H. Lund, F. Hvelplund, and S. Nunthavorakarn, "Feasibility of a 1400MW coal-fired power-plant in Thailand," Applied Energy, vol. 76, pp. 55-64, 2003.

[25] N. H. Afgan and M. G. Carvalho, "Multi-criteria assessment of new and renewable energy power plants," Energy, vol. 27, pp. 739-755, 2002.

[26] P. A. Pilavachi, A. I. Chatzipanagi, and A. I. Spyropoulou, "Evaluation of hydrogen production methods using the analytic hierarchy process,"
International Journal of hydrogen energy, vol. 34, pp. 5294-5303, 2009.

[27] R. Ridolfi, E. Sciubba, and E. Tiezzi, "A multi-criteria assessment of six energy conversion processes for $\mathrm{H} 2$ production," International Journal of Hydrogen Energy, vol. 34, pp. 5080-5090, 2009.

[28] T. Jacobs, "Suitability of fuel cell technology for electricity utility standby power applications," Emergency Power Supplies Conference 2005-IDC Technologies.

[29] N. H. Afgan and M. G. Carvalho, "Sustainability assessment of hydrogen energy systems," International Journal of Hydrogen Energy, vol. 29, pp. 1327-1342, 2004.

[30] P. Konstantopoulou, D. Giannopoulos, and M. Founti, "Multicriteria analysis of hydrogen production technologies," Proceedings International Hydrogen Energy Congress and Exhibition IHEC 2005, Istanbul, Turkey, 13-15 July 2005.

[31] P. A. Pilavachi, S. D. Stephanidis, V. A. Pappas, and N. H. Afgan, "Multi-criteria evaluation of hydrogen and natural gas fuelled power plant technologies," Applied Thermal Engineering, vol. 29, pp. 2228-2234, 2009. 